\title{
The dimension disparity of upper jaw centralist insisivus and the nose size between Batak and Sundanese and the correlation
}

\author{
Rima Tea Kirana Sitepu*, Mochammad Rodian*, Djulaenahningsih* \\ *Department of Oral Biology Faculty of Dentistry Universitas Padjadjaran
}

\begin{abstract}
Introduction: The disparity of tooth dimension and human organ between the race and the other one is determined by heredity. On the identification of dead victims of mass through the teeth have a high contribution in determining one's identity. The study carried out to find out the dimension disparity of upper jaw centralist insisivus and the nose size between Batak and Sundanese and the correlation in a wide selection of programs in helping odontology forensic investigation of mass disasters. Methods: It is a comparative descriptive research. Total samples are 40, consisting of 20 Batak women (group 1) and 20 Sundanese women (group II) aged 18-30 years old. Result: The t-test result shows that $\mathrm{p}$ score of insisivus dimension is 11.21 and nose size of Batak and Sundanese about $0.000,0.000$, and 0.016 . By correlation test of insisivus 11 and 21 with nose size of Batak, the correlation level is 0.851 and 0.925 . The correlation test of insisivus 11 and 21 with the nose size of Sundanese, the correlation level is 0.947 and 0.949. Conclusion: There is a dimension disparity of upper jaw centralis insisivus and nose size between Batak and Sundanese and the correlation. It is in accordance with the statement that race shows the change of the human race because of the influence of the physical form of individuals, such as the shape and size of the teeth, which followed the growth in other parts of the body.
\end{abstract}

Keywords: Dimension of upper jaw insisivus, nose size, Batak, Sundanese

\section{INTRODUCTION}

In recent years, many mass disasters have caused many deaths. Also, crimes with many casualties have not to decrease over time. In cases like this, it is not uncommon to find unknown victims that need to be identified.

Forensic odontology is one of the methods to determine an individuals identity, and this has been known since Before Christ (BC). ${ }^{1}$ The reliability of this identification technique is not only due to its high accuracy so that it almost matches the accuracy of the fingerprint technique, but because of the fact that teeth and bones are the biological materials that are the most resistant to environmental changes and are protected. Tooth is a reliable means of identification if the data recording is made correctly and adequately. Several reasons can be put forward why teeth can be used as a means of identification are as follows, firstly because teeth are the hardest part of the human body with very little organic material and water composition and consist mostly of organic material so that they are not easily damaged ${ }^{2}$, 
located within the protected oral cavity. Second, humans have 32 teeth with precise shapes, and each has five surfaces. ${ }^{3}$ Based on experience in the field, identification of death victims, for example through teeth, has a high contribution in determining a person's identity. In the case of the Bali Bombing I, where victims were identified by teeth reaching $56 \%$, victims of traffic accidents in Situbondo reached $60 \%$, and the loss of Garuda Airlines in Jogyakarta reached $66.7 \%{ }^{3}$

The identification of victims in these cases is needed because the death status of the victim has a considerable impact on the various aspects left behind. This identification is an embodiment of human rights and is a tribute to people who have died. It also determines whether a person is legally dead or alive. ${ }^{3}$

The territory of the Republic of Indonesia is geographically located in a region prone to natural disasters in the form of landslides, earthquakes, volcanic eruptions, tsunamis, floods and others, which can take many victims, and one way to identify victims is by using methods of forensic odontology. Therefore, forensic odontology's role is significant to understand when dealing with victims of mass disasters. ${ }^{3,4}$

In general, there are four primary races, namely Negroid, Australoid, Caucasoid, and Mongoloid. Each race has its own characteristics that can be distinguished both in terms of skin colour, hair, and intraoral conditions. Based on the physical attributes of Indonesian society, the Malay race consists of two sub-groups, namely: Deutro-Malays are Acehnese, Minangkabo, coastal Sumatra, Rejang Lbong, Lampung, Java, Madura, Bali, Bugis, Coastal Manado, Eastern Lesser Sundas , and Malay. While those included in Proto-Malay are Batak, Gayo, Sasak and Toraja, while Jakarta (Betawi), Borneo Malay, Banjar, and Sulawesi coastal residents are a mixture of Deutro and Proto-Malay. In different races, morphological differences are found so that each individual or group has its own characteristics. ${ }^{5}$

By using the width of the maxillary central incisors, this study wanted to prove whether there are a relationship and difference between the width of the maxillary central incisors with the width of the nose in Batak and Sundanese women. The purpose of this study was to determine the differences in maxillary central incisors width and nasal width between Batak and Sundanese women and to determine the correlation between central incisor width and nasal width in Batak and Sunda women.

\section{METHODS}

This research is a comparative descriptive study, which describes the differences comparing one or several variables with other variables.

The population in this study are people with ethnic Bataks and Sundanese who live in Bandung. The population has fulfilled the criteria requirements by testing the authenticity of the sample tribe from the questionnaire by filling in data about two ancestors and above and also their willingness to be sampled. Population criteria were women aged 18-30 years, two maxillary anterior central incisors still complete, not being treated with orthodontics, maxillary 11 and 21 teeth were morphologically normal, no artificial crowns on the maxillary central incisors, no fillings on the maxillary incisors, maxillary central incisors, sample nose shape in normal condition (not deformed, never had plastic surgery.

The tools used in this research are callipers, printing spoons, spatulas and rubber bowls. The materials needed for this research are alginate, water, and stone casts.

\section{RESULTS}

This research is a comparative descriptive study, which describes the differences comparing one or several variables with other variables. The number of samples in this study was 40 women consisting of 20 Batak women (group I) and 20 Sundanese women (group II). Women aged 18-30 years. The population has fulfilled the criteria requirements by testing the authenticity of the sample tribe from the questionnaire by filling in data about two ancestors and above and their willingness to be sampled.

In this study, callipers were used to measure the width of the maxillary central incisors and the width of the nose. Data obtained from the measurements were then processed and carried out using a statistical analysis of the homogeneity test, average two difference test, correlation, and regression formula using SPSS 15.0 Software to see 
The dimension disparity of upper jaw centralist insisivus and the nose size (Rima Tea Kirana Sitepu et al.)

Table 1. Tooth Width 11, 21, and Nose Width in Women from Batak Tribe and Sunda Tribe

\begin{tabular}{|c|c|c|c|c|c|c|}
\hline \multirow{2}{*}{ No } & \multicolumn{3}{|c|}{ BATAK TRIBE } & \multicolumn{3}{|c|}{ SUNDA TRIBE } \\
\hline & Tooth $11(\mathrm{~cm})$ & Tooth $21(\mathrm{~cm})$ & Nose Width $(\mathrm{cm})$ & Tooth $11(\mathrm{~cm})$ & Tooth $21(\mathrm{~cm})$ & Nose Width $(\mathrm{cm})$ \\
\hline 1 & 0,816 & 0,820 & 3,781 & 0,786 & 0,773 & 3,200 \\
\hline 2 & 0,843 & 0,847 & 3,610 & 0,786 & 0,793 & 3,290 \\
\hline 3 & 0,823 & 0,800 & 3,443 & 0,773 & 0,770 & 3,150 \\
\hline 4 & 0,833 & 0,840 & 3,530 & 0,796 & 0,793 & 3,310 \\
\hline 5 & 0,833 & 0,833 & 3,547 & 0,846 & 0,856 & 3,813 \\
\hline 6 & 0,880 & 0,883 & 4,013 & 0,793 & 0,793 & 3,316 \\
\hline 7 & 0,826 & 0,823 & 3,443 & 0,860 & 0,863 & 4,013 \\
\hline 8 & 0,873 & 0,876 & 3,950 & 0,806 & 0,803 & 3,440 \\
\hline 9 & 0,816 & 0,823 & 3,373 & 0,793 & 0,803 & 3,380 \\
\hline 10 & 0,810 & 0,803 & 3,267 & 0,793 & 0,796 & 3,310 \\
\hline 11 & 0,803 & 0,813 & 3,280 & 0,773 & 0,783 & 3,170 \\
\hline 12 & 0,836 & 0,826 & 3,460 & 0,806 & 0,813 & 3,450 \\
\hline 13 & 0,843 & 0,840 & 3,607 & 0,780 & 0,796 & 3,420 \\
\hline 14 & 0,843 & 0,836 & 3,580 & 0,786 & 0,793 & 3,220 \\
\hline 15 & 0,826 & 0,833 & 3,450 & 0,776 & 0,766 & 3,180 \\
\hline 16 & 0,850 & 0,860 & 3,710 & 0,790 & 0,796 & 3,363 \\
\hline 17 & 0,816 & 0,823 & 3,373 & 0,766 & 0,763 & 3,086 \\
\hline 18 & 0,836 & 0,846 & 3,573 & 0,793 & 0,800 & 3,376 \\
\hline 19 & 0,803 & 0,810 & 3,270 & 0,780 & 0,786 & 3,236 \\
\hline 20 & 0,840 & 0,846 & 3,617 & 0,793 & 0,800 & 3,376 \\
\hline $\bar{X}$ & 0,832 & 0,834 & 3,543 & 0,793 & 0,796 & 3,354 \\
\hline SD & 0,02257 & 0,02159 & 0,20125 & 0.02231 & 0,02567 & 0,21887 \\
\hline
\end{tabular}

the difference in maxillary central incisor width with the width of the nose and its correlation.

Based on the measurement of incisor width (11 and 21) and nose width in the two groups, the data in table 4.1 were obtained. Homogeneity test results in each group test, if $p$-value> 0.05 then Ho is accepted. The variance data of the Batak and Sunda tribes on the $11 \mathrm{p}$-value incisor tooth width is 0.858 , the width of the $21 \mathrm{p}$-value incisor tooth value is 0.754 , the RA incisor tooth width $p$-value is 0.897 , and the nose width $p$-value is 0.881 , which means the data variance on each group is homogeneous. After testing the results of homogeneous data, it was continued with t-test, correlation test and regression equation.

The average two different test results (t-test) with a degree of confidence of $95 \%$, in the comparison of the width of the incisors of 11 Batak tribes with Sundanese, the value of $t$ count $(5,989)>t$ table $(2,024)$ and if $p$-value $(0,000)<$ 0.05 then $\mathrm{Ho}$ is rejected. That is, the width of the incisors of 11 Bataks and Sundanese is significantly different. To more clearly see the difference in width of the incisors 11 between the Batak and the Sundanese, the details are presented in Figure 1.

The results of the two different test average (t-test) with a degree of confidence of $95 \%$, the comparison of the width of the incisors of 21 Batak tribes with Sundanese tribe obtained $t$ arithmetic values $(4,733)>t$ tables $(2,024)$ and if p-values $(0,000)<0.05$ then $\mathrm{Ho}$ is rejected. That is, the width of the incisors of 21 Batak tribes and Sundanese are significantly different. To more clearly see the difference in width of the incisor teeth 21 between the Batak and Sundanese, the full details are presented in Figure 2.

The average of two different test results (t-test) in the ratio of maxillary incisors width of the Batak tribe with Sundanese obtained a t count value of $(4,921)>t$ table $(2,024)$ and if $p$-value $(0,000)<0.05$ then Ho was rejected. That is, the width of the RA incisors of the Batak and Sundanese is significantly different. To more clearly see the 


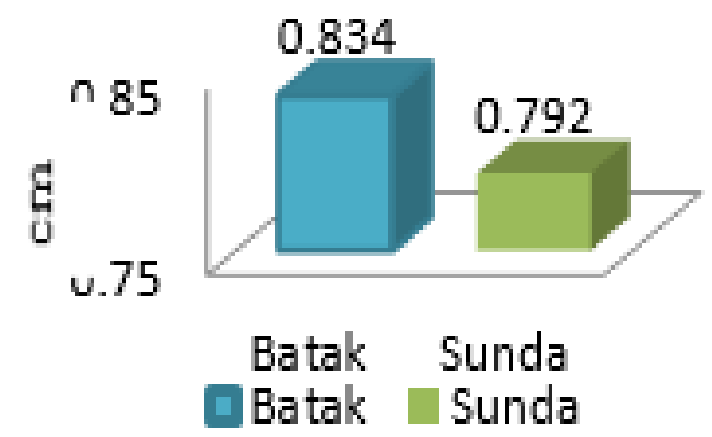

Figure 1. Difference in Tooth incisor width 11 between Batak Tribe and Sunda Tribe

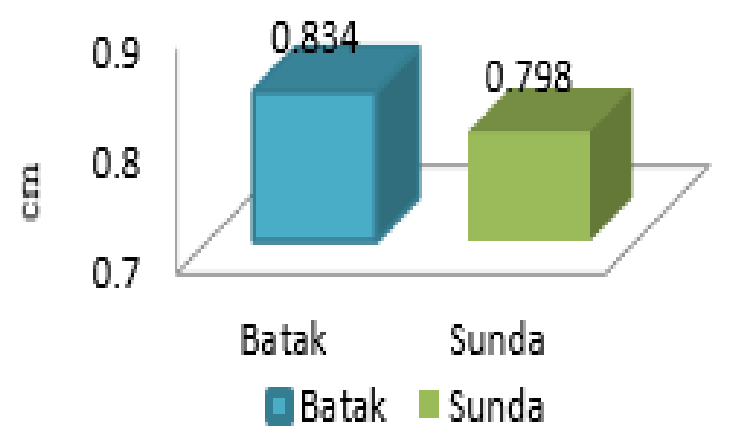

Figure 2. Difference in Tooth incisor width 21 between Batak Tribe and Sunda Tribe

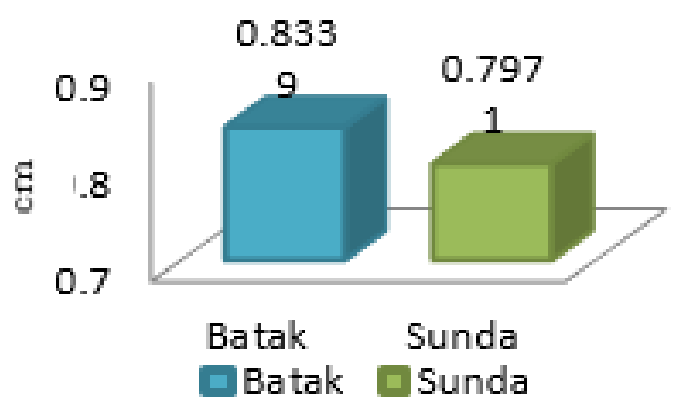

Figure 3. Difference in the width of Central Maxillary Incisor between Batak Tribe and Sunda Tribe

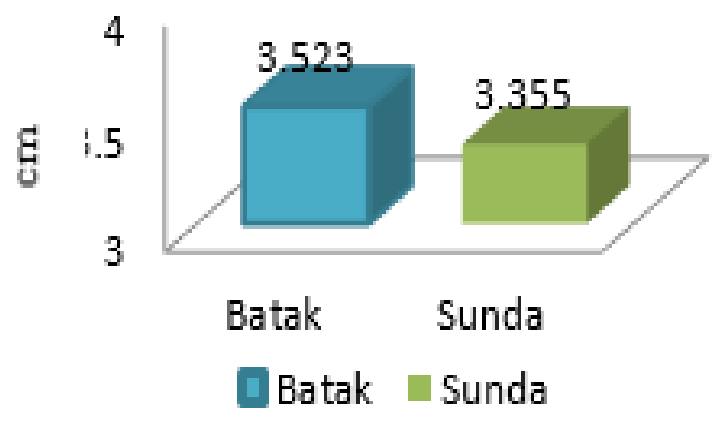

Figure 4. Difference in Nose Width between Batak Tribe and Sunda Tribe difference in the width of the maxillary central incisors between the Batak and the Sundanese, the details are presented in Figure 3.

The results of the two different test average (t-test) in the comparison of the width of the nose of the Batak tribe with the Sundanese tribe obtained at $t$ 8value (2.525) $>\mathrm{t}$ table (2.024) and if p-value $(0.016)<0.05$ then Ho was rejected. This means that the width of the nose of the Batak tribe with the Sundanese is significantly different. To more clearly see the difference in nose width between the Batak tribe with the Sundanese, the detail is presented in Figure 4.

The correlation test results show that the magnitude of the relationship between the width of the incisors of the Batak tribe with the width of the nose of the Batak tribe is 0.851 . This relationship belongs to a very strong category. The test results with the $\mathrm{t}$ statistic obtained $\mathrm{t}$ value $(6,880)>t(2,024)$. This indicates Ho's refusal, which shows that there is a relationship between the width of the 11 incisors of the Batak tribe and the width of the Batak nose. The coefficient of determination of the calculation results obtained by $72.45 \%$. This gives the sense that the width of the Batak nose is influenced by the variable width of the Batak incisors by $72.45 \%$. In comparison, the remaining $27.55 \%$ is contributed by other variables besides the width of the Batak incisors.

Based on the table of the strength of the relationship criteria, it is known that the correlation coefficient of 0.851 is included in the very strong category. This means that there is a very strong relationship between the variable width of the incisors 11 and the width of the Batak nose.

Correlation test results show that the magnitude of the relationship between the width of the 21 incisors of the Batak tribe and the width of the nose of the Batak tribe is 0.925 . This relationship belongs to a very strong category. The test results with the $t$ statistic obtained $t$ value $(10,315)>t(2,024)$. This indicates Ho's refusal to show that there is a relationship between the width of the 21 incisors of the Batak tribe and the width of the nose of the Batak tribe. The coefficient of determination of the calculation results obtained by $85.53 \%$. This gives an understanding that the width of the Batak nose is influenced by the variable width of the Batak incisors by $85.53 \%$. In comparison, the remaining 
$14.47 \%$ is contributed by other variables besides the width of the Batak incisors. Based on the table criteria for the strength of the relationship, we can know that the correlation coefficient of 0.925 is included in the very strong category. This means that there is a very strong relationship between the variable width of the incisors 21 and the width of the Batak nose.

Correlation test results show that the magnitude of the relationship between the width of the Sundanese 11 incisors with the Sunda nose width is 0.947 . This relationship belongs to a very strong category. The results of testing with the $t$ statistic obtained the value of $t(12,492)>t$ $(2,024)$. This indicates Ho's refusal, which shows that there is a relationship between the width of the Sundanese 11 incisors and the width of the Sundanese nose. The coefficient of determination of the calculation results obtained by $89.66 \%$. This gives the sense that the width of the Sundanese nose is influenced by the variable width of the Sundanese incisors by $89.66 \%$. In comparison, the remaining $10.34 \%$ is contributed by other variables besides the width of the Sundanese incisors.

Based on the table criteria for the strength of the relationship, we can know that the correlation coefficient of 0.947 is included in the very strong category. This means that there is a very strong relationship between the variable width of the incisors width of the incisors 11 and the width of the Sundanese nose.

The correlation test results (appendix 7) show that the magnitude of the relationship between the width of the Sundanese 21 incisors and the width of the Sundanese nose is 0.949 . This relationship belongs to a very strong category. The results of testing with the $t$ statistic obtained the value of $t(12,708)>t(2,024)$. This indicates Ho's refusal, which shows that there is a relationship between the width of the Sundanese 21 incisors and the width of the Sundanese nose. The coefficient of determination of the calculation results obtained by $89.97 \%$. This gives an understanding that the width of the Sundanese nose is influenced by the variable width of the 21 incisors of the large Sundase tribe $89.97 \%$. In contrast, the remaining $10.03 \%$ is contributed by other variables besides the width of the Sundanese 21 incisors.

Based on the table criteria for the strength of the relationship, we can know that the correlation coefficient of 0.949 is included in the very strong category. This means that there is a very strong relationship between the variable width of gig insisivus 21 with the width of the Sundanese nose.

\section{DISCUSSION}

Homogeneity test results in each testing group if $p$-value> 0.05 then Ho is accepted. That is, the variance data of the Batak and Sundanese in each RA incisor width, incisor width 11, 21 and nasal width are homogeneous.

After testing the results of homogeneous data, it was continued with t-test, correlation test and regression equation. From the results of the two different test average (t-test) shows the comparison of the Batak and Sundanese tribes with tooth 11, 21 and nasal width groups that with a degree of confidence of $95 \%$, in the ratio of the width of the incisors of 11 Bataks with the Sundanese, $\mathrm{t}$ arithmetic $>\mathrm{t}$ table and if $\mathrm{p}$-value $(0.000)<0.05$ then $\mathrm{Ho}$ is rejected. That is, the width of the incisor teeth 11, 21 and the width of the nose of the Batak and Sundanese are significantly different.

The average two different test results above are based on physical differences, namely physical characteristics, such as the face / facial, body shape, skin colour, etc. between one race with another race. As for dentistry, the differences in facial physical characteristics in the two subclasses mentioned above are discussed. Race, sex, age and culture are all factors that affect a person's tooth size. ${ }^{6}$ It has been proven that the shape, size of the teeth and jaws like other limbs is determined by heredity although environmental factors influence the process of growth and development. ${ }^{7}$

In this study, race is used as a tool to understand variations in humans because it affects to the physical form of individuals; for example, the shape and size of teeth. There is a significant difference between the total face height of the Batak and Javanese, that the face of the Batak is higher than the face of the Javanese, in other words, the Proto-Malay group has a smaller cephalic index than the Deutro-Malay group because the shape of the dolichocephalic head forms a narrow face. ${ }^{8}$ 
Correlation test results show that the incisors 11 and 21 with a Batak tribal nose the degree of correlation is 0.851 and 0.925 . While the incisor tooth correlation test 11 and 21 with the Sundanese nose, the degree of correlation was 0.947 and 0.949 . The magnitude of the relationship between the width of the $11^{\text {th }}$ incisor and the width of the nose of the Batak is very strong. Relationship between the width of incisor tooth 21 with the width of the nose of the Batak tribe, relationship with the width of the incisors 11 with the width of the Sundanese nose, the relation of the width of the incisor 21 with the width of the nose is also included as a very strong category. And based on the results of the correlation test above, it is known that the relationship between incisor width and nasal width is a positive correlation.

The very close relationship between the teeth and nose above is following the statement of facial development in general following the rate of growth of other body parts. The nose and the upper part of the face will develop forward, which is caused by the growth of cartilaginous from the nasal septum. The face extends towards the front and bottom concerning the cranium. ${ }^{9}$

A previous researcher, a University of Indonesia Faculty of Dentistry student, examined anatomic signs on the face that were used as guidelines in determining the size of the anterior maxillary teeth. Anatomic signs used are the size of the nose wing width and the width of the mouth angle. The sample used is an FKG UI student of Deutero Malay descent, and meets the specified criteria. The results obtained indicate that there is a relationship between the width of the upper anterior teeth and the width size nose wings, and the width of the mouth angle. Also, observations show that the nose wing widths of FKG UI students of Deutero Malay descent are wider than the size of the nose wings width of FKG students in the UK and the population in Colorado. ${ }^{10}$

After conducting the correlation test above, there is a regression formula between the width of the maxillary central incisors and the width of the nose in BatakY women $=0.49+0.10 \mathrm{X}$ and in Sundanese women $Y=0.50+0.09 X$ which can be used as a guide for the selection of matching dentures. In patients with complete tooth loss.

\section{CONCLUSION}

Based on the results of the research that has been done, it can be concluded that there are differences and correlations of maxillary central incisors width and nose width between Batak and Sundanese.

\section{REFERENCES}

1. Sidler $M$, Jackowski C, Dirnhofer R, Vock $P$, Thali M. Use of multislice computed tomography in disaster victim identification-advantages and limitations. Forensic Sci Int. 2007; 169(2-3):118-28.

2. Chun K, Choi H, Lee J. Comparison of mechanical property and role between enamel and dentin in the human teeth. J Dent Biomech. 2004;5:1758736014520809.

3. Yayan Al. Peranan Forensik Odontologi Dalam Bencana Massal. 2008. Available from:https:// yayanakhyar.wordpress.com/2008/11/23/ peranan-forensik-odontologi-dalam-bencanamasal/.

4. Departemen Kesehatan Republik Indonesia. Keputusan Menteri Kesehatan Republik Indonesia Nomor 1653/Menkes/SK/XII/2005/ tentang Pedoman Penanganan Bencana Bidang Kesehatan Penanganan Bencana.

5. Artaria DM. Antropologi Dental. $1^{\text {st }}$ ed. Yogyakarta: Graha Ilmu; 2009. p. 15-19.

6. Kaushal S, Patnaik VVG, Agnihotri G. Mandibular canines in sex determination. J Anat Soc Ind. 2003;52(2):119-24.

7. Daulay NW. Proporsi lebar gigi insisivus sentralis dan sentralis rahang atas dan hubungannya dengan konsep golden proportion pada mahasiswa FKG-USU Tahun Angkatan 20062008. Thesis. Medan: USU 2009.

8. Primasari A, Ria N, Sutadi H, Eyanoer PC. Effect of breastfeeding on the difference of dentocraniofacial growth among children aged 3-5 years old malay and batak ethnic. 2007. IOSR;16(6):50-53.

9. Hodgkinson DJ. The Eurasian nose: aesthetic principles and techniques for augmentation of the asian nose with autogenous grafting. Aesthetic Plast Surg. 2007;31(1):28-31. 
10. Soebekti TS. Hubungan antara Lebar Sayap Hidung dan Lebar Mulut dengan Lebar Gigi Anterior Atas Pada Mahasiswa FKG Universitas
Indonesia Keturunan Deutro Melayu.Thesis: Jakarta; UI. 2006. 